\title{
Oral Cysticercosis in a Pediatric Patient: A Rare Case Report with Review
}

\author{
${ }^{1}$ Puneet Goenka, ${ }^{2}$ Aditi Sarawgi, ${ }^{3}$ Kirti Asopa, ${ }^{4}$ Parvind Gumber, ${ }^{5}$ Samir Dutta
}

\begin{abstract}
Cysticercosis is a condition in which a human acts as the intermediate host of the pork tapeworm Taenia solium. Although cysticercosis is a common disease in some regions of the world and can occur in any body site, oral lesions are rare. In this report, we document the case of oral cysticercosis in a 10-year-old boy who sought treatment for an asymptomatic nodule on the dorsal surface of the tongue. A detailed history, thorough clinical examination, morphological appearance and the histopathologic findings of the excised cyst formed the basis for the diagnosis of the lesion.
\end{abstract}

Keywords: Cysticercosis, Parasite, Taenia solium, Tongue.

How to cite this article: Goenka P, Sarawgi A, Asopa K, Gumber $P$, Dutta S. Oral Cysticercosis in a Pediatric Patient: A Rare Case Report with Review. Int J Clin Pediatr Dent 2016;9(2):156-161.

\section{Source of support: Nil}

Conflict of interest: None

Cysticercosis is a condition in which humans act as the intermediate host of Taenia solium, a pork tapeworm. The life cycle of $T$. solium is characterized by different stages of development, requiring various kinds of hosts that can appropriately harbor the eggs (proglottids), the oncospheres, the larvae and the adults. ${ }^{1,2}$ Cysticercosis in humans is common in the cerebral tissue, subcutaneous tissue, muscle and the eye. ${ }^{2}$ The pathological conditions manifested are usually the functional disturbance of the infected tissue such as seizure and visual impairment. ${ }^{3}$

\footnotetext{
${ }^{1}$ Associate Professor, ${ }^{2-4}$ Senior Lecturer, ${ }^{5}$ Senior Professor

${ }^{1}$ Department of Pediatric and Preventive Dentistry, Mahatma Gandhi Dental College, Jaipur, Rajasthan, India

${ }^{2}$ Department of Prosthodontics and Crown and Bridge Mahatma Gandhi Dental College, Jaipur, Rajasthan, India

${ }^{3}$ Department of Pedodontics, Mahatma Gandhi Dental College Jaipur, Rajasthan, India

${ }^{4}$ Department of Oral Pathology and Microbiology, Mahatma Gandhi Dental College, Jaipur, Rajasthan, India

${ }^{5}$ Department of Pedodontics, Government Dental College Rohtak, Haryana, India

Corresponding Author: Puneet Goenka, Associate Professor, Department of Pediatric and Preventive Dentistry Mahatma Gandhi Dental College, Jaipur, Rajasthan, India Phone: 9799243456, e-mail: drpuneetgoenka@yahoo.com
}

The oral cavity is a rare site of involvement by cysticercosis, even in an endemic area. ${ }^{4,5}$ In addition, cysticercosis presenting as a nodule or mass in the tongue is even more rare. ${ }^{6}$ A correct and precise clinical diagnosis is infrequently established and often confused with other benign lesions of the oral cavity. ${ }^{5,7}$ We report here a case of oral cysticercosis that was diagnosed based on the clinical findings, and the morphological and histopathologic appearance of the lesion.

\section{CASE REPORT}

A 10-year-old boy reported to the dental clinic with a swelling on the tongue (Fig. 1). The lesion appeared around 3 years previously as a small localized swelling on the dorsal surface of the tongue, which had increased over the period to the present size. On examination, it was found to be $1.5 \times 1.5 \mathrm{~cm}$ in size, oval, firm, nonmobile with a nonulcerated surface. The patient had no pain but had difficulty in eating. No significant history of fever was reported and the medical history was noncontributory. Mucocele, benign tumors of mesenchymal origin, such as lipoma, fibroma, hemangioma, lymphangioma, granular cell tumor, parasitic cyst and minor salivary gland adenoma were included in the differential diagnosis of this lesion. Fine needle aspiration cytology (FNAC) of the lesion was performed using a 22-gauge hypodermic disposable needle and a $5 \mathrm{ml}$ disposable syringe. Around

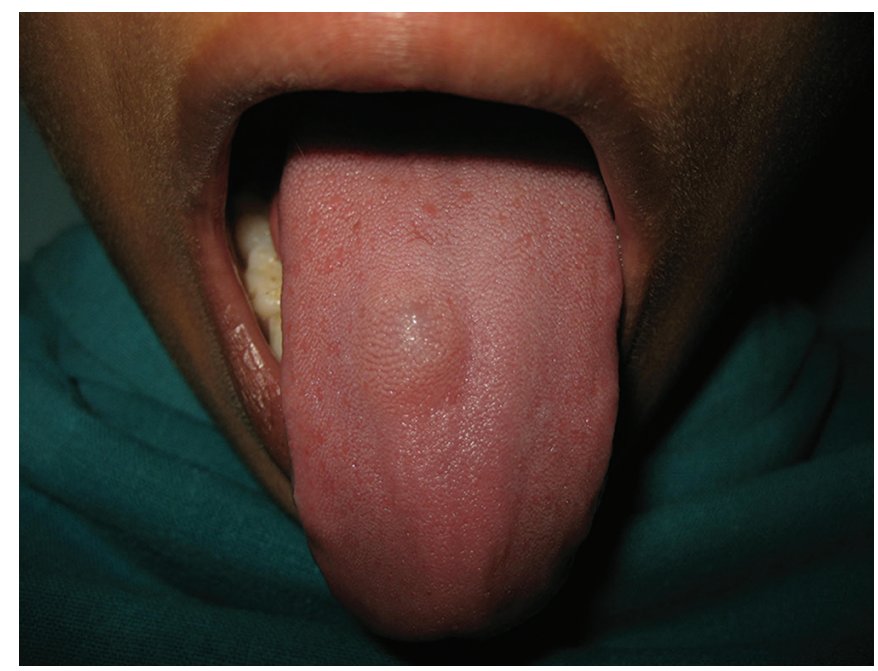

Fig. 1: Swelling on the dorsal surface of the tongue 
$1 \mathrm{ml}$ of clear fluid was collected which showed some pearly white flakes. Smears were prepared and stained with May-Grunwald-Giemsa stain and hematoxylin \& eosin stains and sent for cytological examination. Microscopic evaluation showed a mixed inflammatory reaction with numerous eosinophils, plasma cells and palisading histiocytes.

The cyst was enucleated under local anesthesia and was sent for histopathologic examination (Figs 2 and 3). The incisional wound was sutured using silk suture material (Fig. 4). The surgical site showed an uneventful healing at 1 week postoperative examination (Fig. 5). Histopathology revealed an intramuscular cyst lined by palisaded histiocytes and encircled by fibrocollagenous tissue infiltrated by mixed inflammatory infiltrate including many eosinophils. Although a definitive parasite could not be identified, a small area of calcification was strongly suggestive of a healed parasitic cyst (Fig. 6).

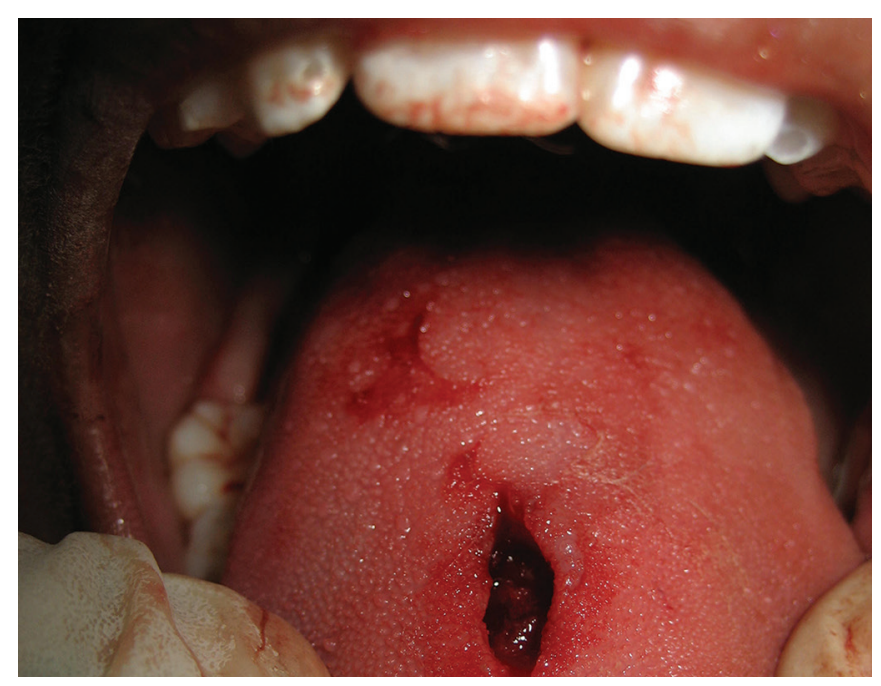

Fig. 2: Surgical excision of the cyst

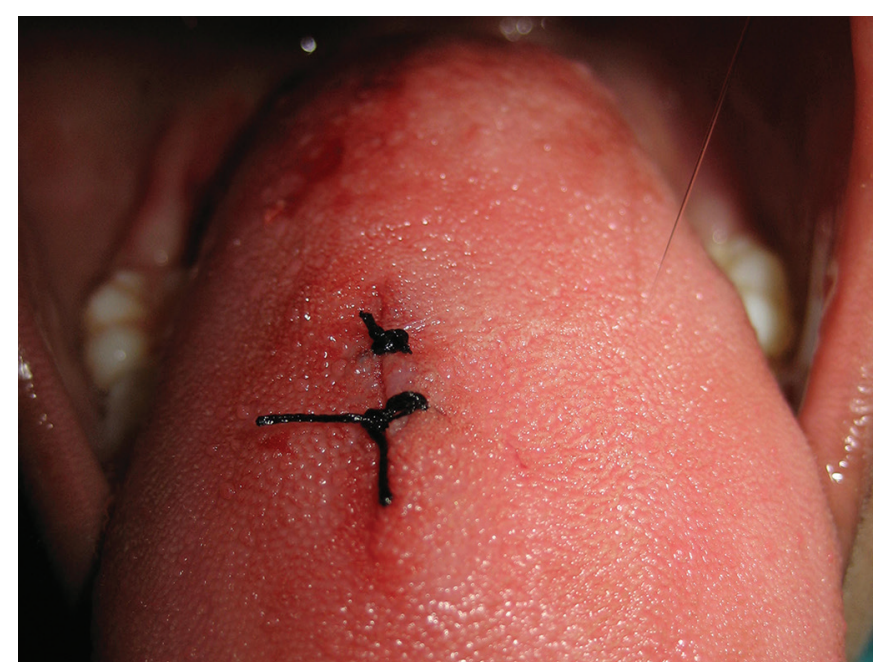

Fig. 4: Sutures placed after surgery
The patient was referred to the Department of Pediatrics for thorough systemic examination. Computed tomography (CT) of the head and neck was found to be unremarkable. Stool, urine and blood failed to show active parasitosis. Oral antihelminthic drug was planned for the patient. To avoid any immune response to the parasitic byproducts, steroids were started first. Prednisolone $20 \mathrm{mg} 8$ hourly was administered orally for 5 days. On the 4th day, Albendazole $600 \mathrm{mg}$ once daily was started and was continued for 28 days. The patient was monitored for 24 hours after administration of the first dose of Albendazole. The patient was scheduled for periodic examinations to assess his clinical status, which remained satisfactory for 3 years of follow-up.

\section{DISCUSSION}

Taenia solium (tape worm) is a hermaphrodite cestode for which human beings are the only definitive host. The adult worm is composed of the head (scolex) and

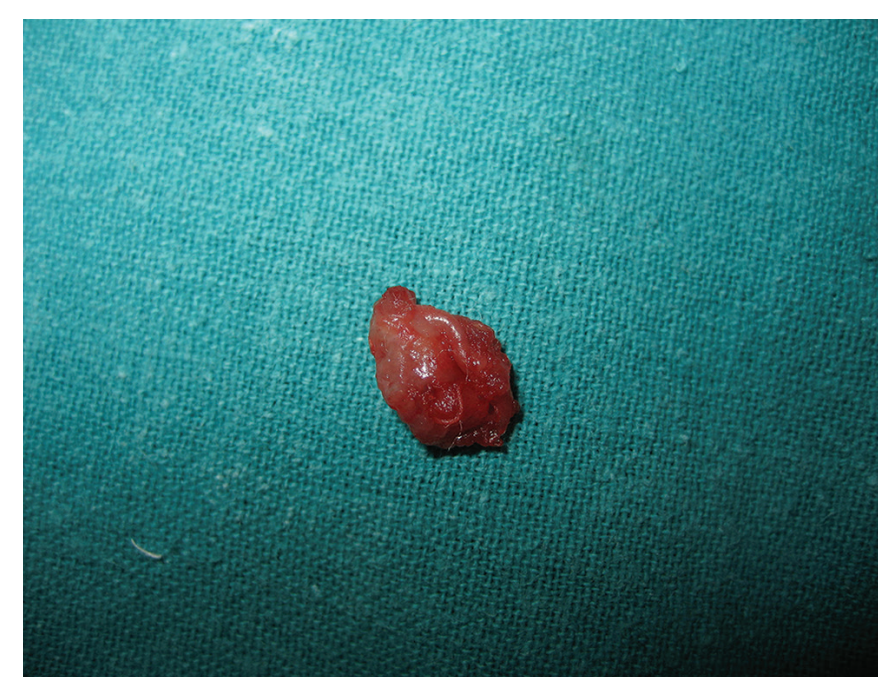

Fig. 3: The enucleated cyst

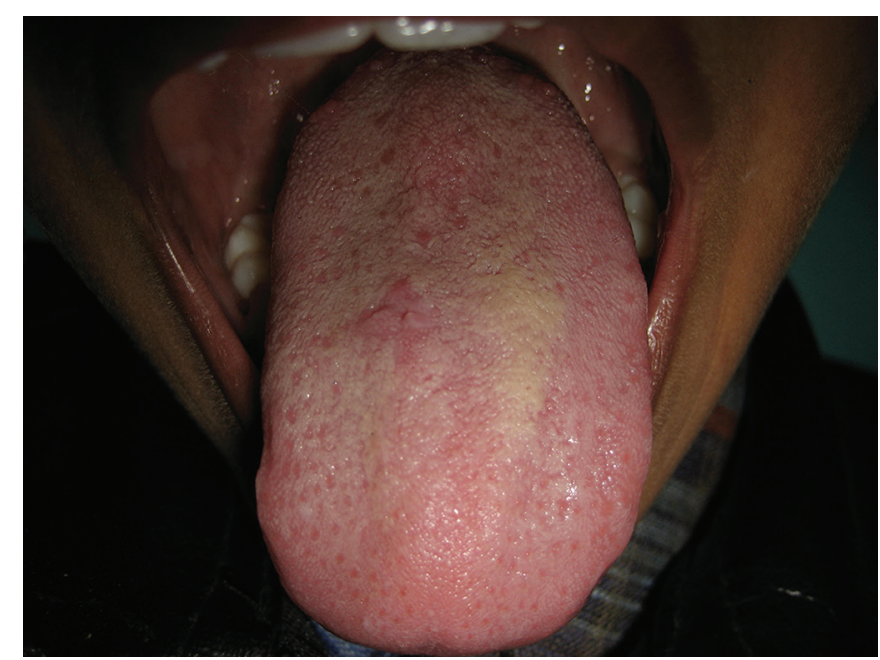

Fig. 5: Healed tongue after surgery 


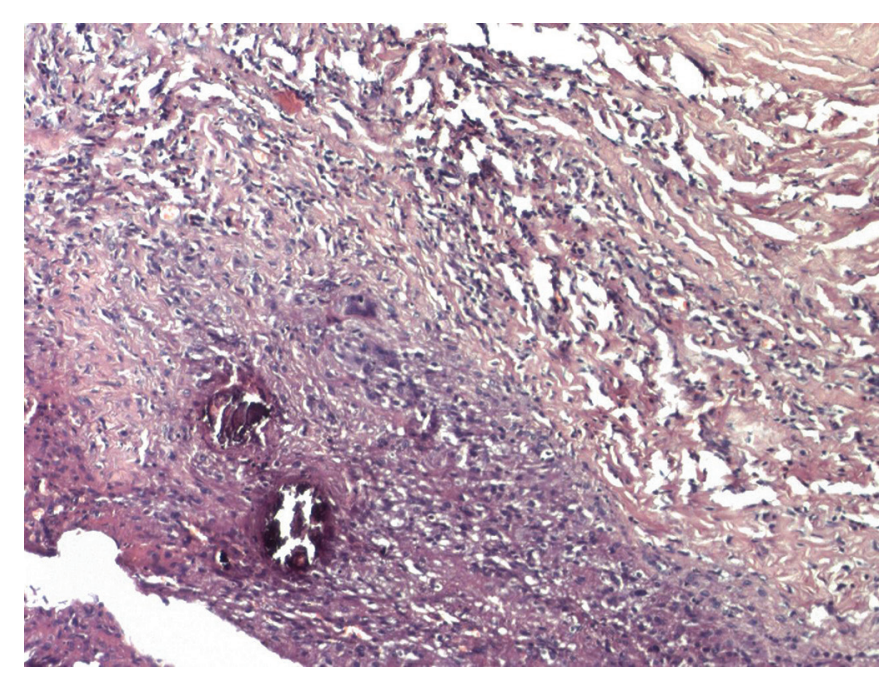

Fig. 6: Photograph showing the histopathology of the excised cyst

numerous proglottids and may reach up to $6-10 \mathrm{ft}$. The proglottids (each containing 50,000-60,000 fertile eggs) are liberated by the humans in excreta. Cysticercosis develops when these eggs are ingested by humans and pigs (intermediate hosts) and oncospheres (embryos) are liberated by the action of gastric acid and intestinal juices. Infestation is usually via the oral route after consumption of contaminated food or drinks, or by unclean hands (feco-oral route) or, rarely, by reflux of the proglottid from the intestines into the stomach. ${ }^{7}$ The oncospheres and larvae that are formed in the stomach cross the bowel wall and actively reach destinations like brain, skeletal muscle, eye and subcutaneous structures through blood and lymphatics. Reaching these organs, the larvae become fluid-filled cysts known as the 'bladder worm' or cysticerci. . $^{8,9}$ The pictographic description of the tapeworm life cycle has been shown in Figure 7.

Although cysticercosis is highly prevalent in some parts of the world (India, Indonesia, Africa, Peru and Mexico), oral and perioral lesions are relatively rare. ${ }^{10}$ In a large series of 450 cases, Dixon and Lipscomb ${ }^{11}$ detected oral involvement in only eight cases $(1.8 \%)$. The condition in pediatric age group ( $0-18$ years) involving the oral structures is even rarer. A review of few reported cases of cysticercosis in pediatric age group is shown in Table 1.

Although involvement of the tongue musculature by cysticercosis is common in swine, this location is rare in humans. No explanation for this phenomenon has been given, but some authors have suggested that the high muscular activity and metabolic rate of these muscles in humans might act against the lodgment and development of the cysticercus in this location. ${ }^{12}$ According to the literature, oral cysticerci usually elicit a clinical diagnosis of mucocele, or a benign tumor of mesenchymal origin, such as lipoma, fibroma, hemangioma, lymphangioma, granular cell tumor

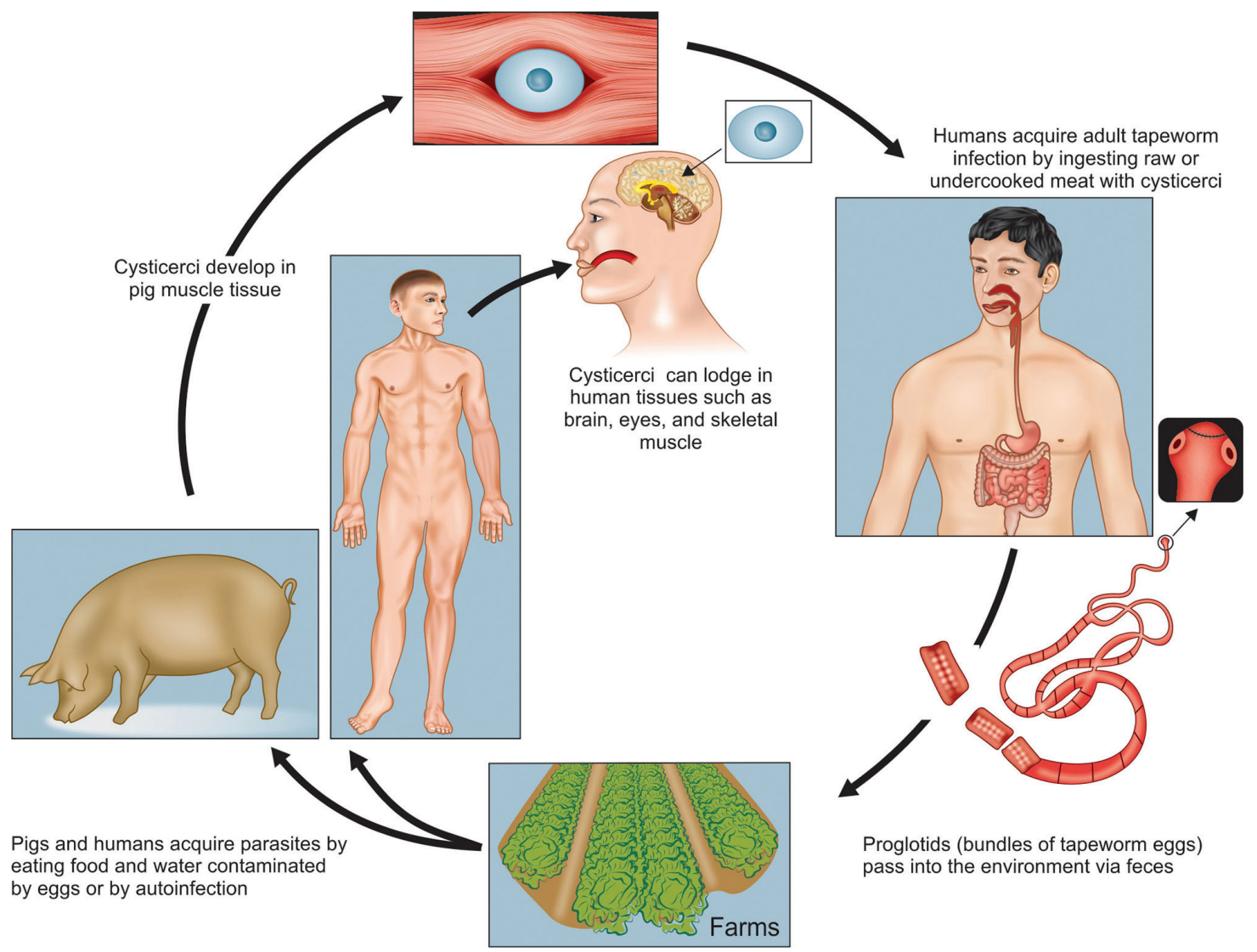

Fig. 7: Photograph showing the life cycle of Taenia solium 
Oral Cysticercosis in a Pediatric Patient

Table 1: Reported cases of oral cysticercosis in pediatric age group

\begin{tabular}{|c|c|c|c|c|}
\hline S. No. & Age & Gender & Location & Author \\
\hline 1. & 3 & $\mathrm{~F}$ & Tongue & Rao et $\mathrm{al}^{31}$ \\
\hline 2. & 6 & $\mathrm{~F}$ & Upper lip & Hansen and Allard ${ }^{32}$ \\
\hline 3. & 12 & M & Lower lip & Hansen and Allard ${ }^{32}$ \\
\hline 4. & 7 & $\mathrm{~F}$ & Tongue & Ostrofsky and Baker ${ }^{33}$ \\
\hline 5. & 7 & $\mathrm{~F}$ & Buccal mucosa & Romero De Leon and Aguirre ${ }^{2}$ \\
\hline 6. & 9 & $\mathrm{~F}$ & Submental area & Timosca and Gavrilita ${ }^{34}$ \\
\hline 7. & 9 & $\mathrm{~F}$ & Buccal mucosa & Delgado-Azañero et al ${ }^{10}$ \\
\hline 8. & 15 & $\mathrm{~F}$ & Buccal mucosa & Delgado-Azañero et al ${ }^{10}$ \\
\hline 9. & 13 & M & Lower lip & Delgado-Azañero et al ${ }^{10}$ \\
\hline 10. & 18 & M & Upper lip & Delgado-Azañero et al ${ }^{10}$ \\
\hline 11. & 14 & $\mathrm{~F}$ & Upper lip & Delgado-Azañero et al ${ }^{10}$ \\
\hline 12. & 6 & M & Lower lip & Delgado-Azañero et al ${ }^{10}$ \\
\hline 13. & 11 & M & Tongue & Lustmann and Copelyn ${ }^{35}$ \\
\hline 14. & 18 & M & Lip (angle of mouth) & Nigam et $\mathrm{al}^{14}$ \\
\hline 15. & 6 & $\mathrm{~F}$ & Tongue & Saran et $\mathrm{al}^{7}$ \\
\hline 16. & 8 & M & Tongue & Saran et $\mathrm{al}^{7}$ \\
\hline 17. & 12 & M & Tongue & Saran et $\mathrm{al}^{7}$ \\
\hline 18. & 3 & M & Tongue & Saran et $\mathrm{al}^{7}$ \\
\hline 19. & 11 & $\mathrm{M}$ & Buccal mucosa & Saran et $\mathrm{al}^{7}$ \\
\hline 20. & 11 & M & Submental & Mahindra et al ${ }^{36}$ \\
\hline 21. & 7 & $\mathrm{~F}$ & Tongue and upper lip & Mukesh et al ${ }^{37}$ \\
\hline 22. & 10 & $\mathrm{~F}$ & Tongue & Mukesh et $\mathrm{al}^{37}$ \\
\hline 23. & 18 & $\mathrm{~F}$ & Upper lip & Mukesh et $a^{37}$ \\
\hline 24. & 5 & $\mathrm{~F}$ & Tongue, subcutaneous & Webb et $\mathrm{al}^{38}$ \\
\hline 25. & 12 & $\mathrm{~F}$ & Tongue & Puppin et $\mathrm{al}^{39}$ \\
\hline 26. & 12 & $\mathrm{~F}$ & Tongue & Gupta and Gupta ${ }^{40}$ \\
\hline 27. & 11 & M & Upper lip & Deshmukh et $\mathrm{al}^{41}$ \\
\hline 28. & 10 & M & Tongue & Goenka et $a^{*}$ \\
\hline
\end{tabular}

${ }^{*}$ Current article

or a minor salivary gland adenoma. ${ }^{1,4,13,14}$ The lesion presented in this case as a firm nodule, thus making lipoma and hemangioma as less likely diagnosis. The consistency of lipoma is usually soft to fluctuant and histologically is composed of adipocytes that are subdivided into lobules by septet of fibrous connective tissue. ${ }^{15}$ Moreover, hemangioma presents as a flat or raised lesion, usually deep red or bluish which is often traumatized leading to surface ulcerations and secondary infections. Although tongue is the most common intraoral site for lymphangioma, it is a less probable diagnosis as they usually are present since birth or appear at a very early age. The histopathologic findings were also not in favor of either hemangioma or lymphangioma.

Very often the clinical presentation of granular cell tumors is very similar to the one presented in this case, i.e. a solitary, slow growing, painless, smooth and sessile mucosal swelling with a firm texture and color varying from normal or slightly pale to yellowish. The lesion can appear at any age with a peak age of 40-60 years and a female predilection of $2: 1{ }^{16}$ Microscopically, granular cell tumors exhibit round or polygonal cells with small excentrically placed nuclei and abundant pale eosinophilic granular cytoplasm. The cells are usually arranged in unencapsulated sheets but may also be found in cords and nests. The histopathologic picture found in the presented case did not resemble the one described for granular cell tumor. Thus, granular cell tumor was also ruled out as the diagnosis for this case. ${ }^{17-20}$

Although larvae or its fragments were neither identified in FNAC nor in histopathologic examination of the postexcision specimen, based on clinical and morphological pointers the lesion was suggested to be a parasitic cyst. Aspiration of a clear fluid with white flakes, intramuscular site, mixed inflammatory response with predominance of eosinophils and plasma cells, presence of palisading histiocytes and calcified structures on microscopic examination were highly suggestive of an intraoral cysticercosis.

Oral cysticerci are firm nodules on palpation because of its high intraluminal pressure. ${ }^{10}$ In contrast to the severity of the disease in cerebral, ocular or cardiac sites, oral lesions are usually well tolerated; however, it is important to carry out a detailed study in every case to exclude the presence of the parasite in other sites. In order of frequency, the tissues affected by cysticercosis are subcutaneous layers, brain, muscles, heart, liver, lungs and peritoneum. ${ }^{21}$ The intensity of the signs and symptoms produced by cerebral cysticerci (headaches, acute obstructive hydrocephalus and epileptic seizures) 
depends on the number of invasive oncospheres present and their anatomic location. In some cases, the symptoms may even suggest the presence of a cerebral neoplasm. ${ }^{22}$ Iridocyclitis, secondary glaucoma and cardiac arrhythmias may also occur. ${ }^{17}$

Radiologic imaging, serology and tissue biopsy can be used to confirm a diagnosis of cysticercosis. Imaging techniques, in particular $\mathrm{CT}$ and magnetic resonance imaging (MRI), are of great value to diagnose cerebral cysticercosis. ${ }^{23,24}$ The immunodiagnosis of human cysticercosis can be achieved in sera, cerebrospinal fluid and saliva by either enzyme-linked immunosorbent assay (ELISA) or enzyme-linked immunoelectrotransfer blot. ${ }^{25,26}$ Enzyme-linked immunoelectrotransfer blot has a specificity and sensitivity superior to ELISA for the diagnosis of cysticercosis. ${ }^{27}$ Enzyme-linked immunoelectrotransfer blot for cysticercosis antibodies is highly sensitive in patients with multiple intracranial lesions, but it is less sensitive in patients with single or calcified lesions. ${ }^{28}$ Apparently, imaging techniques are more reliable than serological tests for the diagnosis of neurocysticercosis. ${ }^{22}$

Oral cysticerci are usually easy to excise and the prognosis is good. In all cases, simple surgical excision seems to be sufficient to ensure complete removal of the lesions without postoperative complications. Treatment of multiple cysts may be unnecessary in asymptomatic individuals after confirmation of diagnosis, but in every case a thorough clinical and epidemiological survey has to be done to identify the possible source and magnitude of the problem in a given community. ${ }^{10}$ In the present case also, a simple surgical excision of the lesion was done, which was well tolerated by the patient.

Albendazole is currently the drug of choice for the treatment of systemic cysticercosis. It is an imidazole with antihelminthic properties. It was first used to treat human neurocysticercosis in $1987 .{ }^{28}$ Praziquantel (isoquinoline) is a broad-spectrum antihelminthic, whose efficacy to treat parenchymal neurocysticercosis has been confirmed in several long-term follow-up studies throughout the world. ${ }^{29}$ Clinical trials for the treatment of neurocysticercosis have revealed that both Albendazole and Praziquantel reduce the number of cerebral lesions as demonstrated by serial MRI and $\mathrm{CT}$ scans. ${ }^{30}$ Considering the epidemic nature and the severity of the disease, a future therapeutic alternative to regulate the transmission of helminthic disease could be vaccination.

\section{REFERENCES}

1. Pinswasdi P, Charoensiri DJ. Cysticercosis in labial tissue. Case report. Aust Dent J 1997 Oct;42(5):319-321.
2. Romero De Leon E, Aguirre A. Oral cysticercosis. Oral Surg Oral Med Oral Pathol Oral Radiol Endod 1995 May;79(5): 572-577.

3. Tandon PN. Cerebral cysticercosis. Neurosurg Rev 1983; 6(3):119-127.

4. Nigam S, Singh T, Mishra A, Chaturvedi KU. Oral cysticercosis - report of six cases. Head Neck 2001 Jun;23(6):497-499.

5. Martelli H, Melo Filho MR, Santos LAN. Oral cysticercosis. Braz J Oral Sci 2006;5(18):1109-1111.

6. Pandey SC, Pandey SD. Lingual cysticercosis. Indian J Plast Surg 2005 Jul-Dec;38(2):160-161.

7. Saran RK, Rattan V, Rajwanshi A, Nijkawan R, Gupta SK. Cysticercosis of the oral cavity: report of five cases and a review of literature. Int J Paediatr Dent 1998 Dec;8(4):273-278.

8. Strickland GT. Hunter's tropical medicine, 6th edn. Philadelphia: W. B. Saunders Co.; 1984. p. 783-786.

9. Nash TE, Neva FA. Recent advances in the diagnosis and treatment of cerebral cysticercosis. N Engl J Med 1984 Dec 6;311(23):1492-1496.

10. Delgado-Azañero WA, Mosqueda-Taylor AM, Carlos-Bregni R, Muro-Delgado RD, Diaz-Franco MA, Contreras-Vidaurre E. Oral cysticercosis: a collaborative study of 16 cases. Oral Surg Oral Med Oral Pathol Oral Radiol Endod 2007 Apr;103 (4): 528-533.

11. Dixon HB, Lipscomb FM. Cysticercosis, an analysis and follow up of 450 cases. Privy Council, Med Res Council, Special Report Series No: 229. London: Her Majesty's Stationary Office; 1961.

12. Sharma AK, Misra RS, Mukherjee A, Ramesh V, Jain RK. Oral cysticercosis. Int J Oral Maxillofac Surg 1986 Jun;15(3):349-351.

13. De Souza PE, Barreto DC, Da Silva Fonseca LM, Batista de Paua AM, Silva E, Gomez RS. Cysticercosis of the oral cavity: report of seven cases. Oral Dis 2000 Jul;6(4):253-255.

14. Amatya BM, Kimula Y. Cysticercosis in Nepal: a histopathological study of 62 cases. Am J Surg Pathol 1999;23:1276-1279.

15. Chidzonga MM, Mahomva L, Marimo C. Gigantic tongue lipoma: a case report. Med Oral Patol Oral Cir Bucal 2006 Aug 1;11(5):E437.

16. Nagaraj PB, Ongole R, Bhujanga-Rao BR. Granular cell tumor of the tongue in a 6-year-old girl - a case report. Med Oral Patol Oral Cir Bucal 2006 Mar 1;11(2):E162-E164.

17. Sousa FB, Osterne RLV, Matos Brito RG, Alves APNN, Soares ECS, Costa FWG. Oral granular cell tumor: a study of twelve cases in a Brazilian population. J Clin Exp Dent 2010;2(4):e178e182.

18. Eguia A, Uribarri A, Gay Escoda C, Crovetto MA, MartinezConde R, Aguirre JM. Granular cell tumor: report of 8 intraoral cases. Med Oral Patol Oral Cir Bucal 2006 Aug 1;11(5):E425E428.

19. Tosios K, Rallis G, Vallianatou D, Vlachodimitropoulos D. Yellow White tumor on the floor of the mouth. Oral Surg Oral Med Oral Pathol Oral Radiol Endod 2006 Jun;101(6):701-704.

20. Becelli R, Perugini M, Gasparini G, Cassoni A, Fabiani F. Abrikossoff's tumor. J Craniofac Surg 2001 Jan;12(1):78-81.

21. Wortman PD. Subcutaneous cysticercosis. J Am Acad Dermatol 1991 Aug;25(2 Pt 2):409-414.

22. Miranda A. Neurocysticercosis. Am Fam Physician 1993 Apr;47(5):1193-1197.

23. Richards F, Schantz PM. Laboratory diagnosis of cysticercosis. Clin Lab Med 1991 Dec;11(4):1011-1028.

24. Puri V, Gupta RK. Magnetic resonance imaging evaluation of focal computed tomography abnormality in epilepsy Epilepsia 1991 Jul-Aug;32(4):460-466. 
25. Flisser A, Plancarte A, Correa D. New approaches in the diagnosis of Taenia solium cysticercosis and taeniasis. Ann Parasitol Hum Comp 1990;65 )Suppl) 1:95-98.

26. Diaz JF, Verastegui M, Gilman RH, Tsang VC, Pilcher JB, Gallo C, Garcia HH, Torres P, Montenegro T, Miranda E. Immunodiagnosis of human cysticercosis (Taenia solium): a field comparison of an antibody enzyme linked immunosorbent assay (ELISA). Am J Trop Med Hyg 1992 May;46(5): 610-615.

27. Wilson M, Bryan RT, Fried JA, Ware DA, Schantz PM, Pilcher JB, Tsang VC. Clinical evaluation of the cysticercosis enzyme-linked immunoelectro-transfer blot in patients with neurocysticercosis. J Infect Dis 1991 Nov;164(5):1007-1009.

28. Escobendo F, Penagos P, Rodriguez J, Sotelo J. Albendazole therapy for neurocysticercosis. Arch Intern Med 1987 Apr; 147(4):738-741.

29. Del Brutto $\mathrm{OH}$, Sotelo J, Roman GC. Therapy for neurocysticercosis: a reappraisal. Clin Infect Dis 1993 Oct;17(4): 30-35.

30. Takayanagui OM, Jardim E. Therapy for neurocysticercosis: comparison between Albendazole and Praziquentel. Arch Neurol 1992 Mar;49(3):290-294.

31. Rao PLNG, Radhakrishna K, Kapadia RD. Cysticercosis of the tongue. Int J Paediatric Otorhinolaryngol 1990 Nov;20(2): 159-161.
32. Hansen LS, Allard RHB. Encysted parasitic larvae in the mouth. J Am Dental Assoc 1984 Apr;108(4):632-636.

33. Ostrofsky MK, Baker MA. Oral cysticercosis: three case reports. J Dental Assoc SA 1975 Jun;30(6):535-537.

34. Timosca G, Gavrilita L. Cysticercosis of maxillo-facial region. Oral Surg Oral Med Oral Pathol 1974;37(3):390-400.

35. Lustmann J, Copelyn M. Oral cysticercosis: review of literature and report of two cases. Int J Oral Surg 1981 Oct;10(5):371-375.

36. Mahindra S, Daljit R, Sohail MA, Maheshwari HB. Cysticercosis in the practice of otolaryngology. Acta Otolaryngol 1981 Jul-Aug;92(1-2):189-191.

37. Mukesh S, Kacker SK, Kapila K. Cysticercosis of the oral cavity: a clinicopathological study of ten and a half years. J Indian Dent Assoc 1986 Jul;58(7):257-259.

38. Webb J, Seidal J, Correll WA. Multiple nodules on the tongue of a patient with seizures. J Am Dental Assoc 1986 May;112(5): 701-702.

39. Puppin D, Cavegn BM, Delmaestro D. Subcutaneous cysticercosis of the tongue mimicking a tumour. Int J Dermatol 1993 Nov;32(1):818-819.

40. Gupta SC, Gupta SC. Cysticercosis of the tongue. ENT J 1995 Mar;74(3):174-178

41. Deshmukh Avadhani A, Tupkari JV, Sardar M. Cysticercosis of the upper lip. J Oral Maxillofac Pathol 2011 May;15(2): 219-222. 